\title{
MEMBANGUN MODERASI BERAGAMA DENGAN PARENTING WASATHIYAH DAN PERPUSTAKAAN QUR'ANI DI TAMAN PENDIDIKAN AL-QUR'AN
}

\author{
Benny Afwadzi \\ Universitas Islam Negeri Maulana Malik Ibrahim Malang, Malang, Indonesia \\ afwadzi@pai.uin-malang.ac.id
}

\begin{abstract}
Abstrak: Persoalan radikalisme dan terorisme di Indonesia sudah sangat nampak kian berbahaya. Bahkan, aksi tersebut sudah menyeret anak-anak di dalamnya. Misalnya saja bom bunuh diri di tiga gereja Surabaya pada tahun 2018 silam yang juga melibatkan empat orang anak yang notebenenya masih sekolah, bahkan yang menyedihkan dua diantaranya masih berada pada tingkatan Sekolah Dasar. Pengabdian ini berupaya untuk turut berkontribusi dalam menyelesaikan persoalan tersebut dengan bentuk pengabdian di lembaga pendidikan dasar Islam, yakni Taman Pendidikan al-Qur'an (TPQ) dengan kerangka besar moderasi beragama. Kegiatan yang dijalankan ada dua, yakni parenting yang bernuansa wasathiyah dan perpustakaan Qur'ani. Dengan metode Participatory Action Research (PAR) dan dilaksanakan dalam jangka waktu tiga bulan, yaitu Juli sampai September 2020, pengabdi sampai pada kesimpulan bahwa dua kegiatan tersebut cukup bisa membangun pemahaman keagamaan masyarakat TPQ menjadi lebih moderat, atau paling tidak, bisa lebih memperkuat moderasi beragama yang sudah mereka yakini. Mereka menyadari bahwa harus adanya kecintaan terhadap Indonesia dan adanya kesadaran bahwa perbuatan radikalisme dan terorisme merupakan perbuatan yang keji. Meskipun demikian, pengabdi menyadari bahwa perlu waktu yang jauh lebih lama untuk bisa merubah pemahaman ke arah yang benar-benar moderat.
\end{abstract}

Kata Kunci: moderasi; parenting wasathiyah; perpustakaan; Taman Pendidikan al-Qur'an

\begin{abstract}
The problems of radicalism and terrorism in Indonesia have become increasingly dangerous. The actions have already dragged children into it. For example, the suicide bombing in three churches in Surabaya in 2018 involved four schoolchildren; sadly, two of them were still at the elementary school level. This community service program seeks to resolve these problems by implementing religious moderation in Taman Pendidikan al-Qur'an (TPQ). The program comprised two activities; parenting with wasathiyah nuances and the Qur'anic library and applied Participatory Action Research (PAR). It was implemented within a period of three months, from July to September 2020. The results show that both programs are able to construct a moderate religious understanding of the TPQ community, or at the very least, reinforce the existing religious moderation they already have. They realized that people must love their homeland (Indonesia) and that radicalism and terrorism are heinous. Nonetheless, it will take much longer to change their understanding into a truly moderate one.
\end{abstract}

Keywords: moderation; parenting wasathiyah; library; Taman Pendidikan al-Qur'an

\section{Pendahuluan}

Persoalan radikalisme merupakan masalah serius yang menimpa bangsa Indonesia dewasa ini. Banyak sekali fenomena radikalisme yang terjadi dan kemudian menimbulkan korban jiwa di masyarakat yang tidak sedikit (Hambali, 2010; Lutfiyah, Tamam, \& Muniroh, 2016; Sumbulah, 2009). Kasus terakhir yang sempat ramai adalah bom bunuh diri oleh radikalis Jamaah Anshorud Daulah di tiga gereja Surabaya yang menewaskan 13 orang pada tanggal 13 Mei 2018. Hal yang mengenaskan adalah bom bunuh diri tersebut dilakukan oleh satu keluarga, yakni sepasang suami istri dan juga melibatkan empat orang anak-anaknya. Tentu saja cukup mengherankan, mengingat anak-anak tersebut masih berusia sekolah: anak sulung masih 
berada di tingkatan SMA, yang kedua masih SMP, dan anak ketiga dan keempat masih duduk di SD kelas lima dan dua (Adhiarso, 2019; Wicaksono, 2018).

Melihat fenomena radikalisme di Indonesia yang kian berbahaya sebagaimana dipaparkan di atas, menjadi sangat penting melakukan langkah yang solutif di masyarakat secara langsung. Langkah solutif ini dilakukan dengan memberikan pengajaran tentang moderasi Islam di lingkungan pendidikan Islam (Cahyono \& Hamzah, 2018; Suprapto, 2014), mengingat selama ini para radikalis menjadikan Islam sebagai tameng aksi-aksi teror yang dilakukannya, sehingga Islam dianggap sebagai agama yang radikal, atau dengan bahasa yang agak menusuk "Radikalisme Islam" (Rubaidi, 2010). Terlebih lagi pendidikan terhadap anak usia dini, jika sejak kecil mereka ditanamkan dengan kebencian, maka mereka akan tumbuh sebagai seseorang pendendam. Mereka juga terkadang dieksploitasi oleh orang-orang dewasa yang tidak paham dengan kebinekaan. Peristiwa pawai anak-anak menjelang Ramadhan tahun 2016 yang diwarnai dengan menebarkan hatespeech dan kebencian kepada Ahok, yang kala itu terkena kasus penistaan agama merupakan contohnya (Sumbulah, 2018). Dengan alasan itulah pendidikan Islam anak di usia dini menjadi sarana yang penting untuk mengembangkan pemikiran moderat dalam beragama, yang dalam pengabdian ini difokuskan pada Taman Pendidikan al-Qur'an atau yang biasa disebut TPQ.

TPQ yang menjadi objek pengabdian adalah TPQ Nurul Iman yang berada di Perumahan Karangploso View Desa Ngenep Kecamatan Karangploso Kabupaten Malang. TPQ ini berdiri pada tahun 2014 dan sejak 2016 pembelajarannya dilakukan di Masjid al-Fath Perumahan Karangploso View dengan jumlah santri berjumlah 56 anak. Adapun pemilihan TPQ tersebut sebagai objek terdiri atas beberapa alasan. Pertama, TPQ ini berada di lingkungan perumahan yang menaungi berbagai aliran keagamaan yang bermacam-macam dan sangat dimungkinkan ada doktrin-doktrin radikal di kalangan warganya. Kedua, Kecamatan Karangploso termasuk daerah yang cukup rawan dari para teroris, misalnya pada tahun 2016 ditangkap beberapa teroris yang berdomisili di Perumahan Griya Permata Alam, Perumahan Permata Regency, dan Perumahan Green Hils (Aminuddin, 2016). Hal yang perlu diketahui adalah, ketiganya merupakan tetangga perumahan Karangploso View yang menjadi objek pengabdian ini. Ketiga, TPQ Nurul Iman merupakan sarana vital untuk menyuarakan pemikiran keagamaan yang moderat melalui institusi pendidikan Islam di perumahan Karangploso View.

Secara umum, wali santri dan guru TPQ Nurul Iman merupakan warga perumahan Karangploso View. Sebagaimana perumahan pada umumnya, masyarakat Karangploso View adalah masyarakat yang heterogen, tidak hanya dihuni oleh satu golongan saja. Sebagian besar berlatar belakang Nahdlatul Ulama (NU), sebagian lagi Muhammadiyah, dan sebagian lagi berlatar belakang selain NU dan Muhammadiyah. Di perumahan ini biasa ada kegiatan tahlilan, dzibaan, aqiqahan, dan beberapa kegiatan lain yang mempunyai background Nahdliyyin. Meskipun kegiatan-kegiatan tersebut berasal dari Nahdliyyin, namun non-Nahdhiyyin pun biasa mengikuti kegiatan-kegiatan itu, kecuali sebagian warga yang memang benar-benar eksklusif dan tidak mau membaur dengan masyarakat. Dalam banyak hal, banyak terjadi kerjasama antar warga perumahan Karangploso View secara umum, dan jamaah Masjd al-Fath secara khusus, misalnya seperti kunjungan jamaah masjid yang sakit dan kerja bakti di lingkungan masjid. 
Heterogenitas wali santri dan santri pun sebenarnya tidak menjadi masalah ketika proses pembelajaran dilakukan di TPQ Nurul Iman, karena masing-masing sudah memahami perbedaan yang ada. Di Masjid al-Fath sekalipun, imam senantiasa berganti-ganti dengan perbedaan latar belakangnya supaya mendamaikan satu dengan lainnya. Di TPQ sendiri, jika ada kegiatan yang memaksa untuk mengadopsi salah satu golongan, maka dilakukan dengan cara Nahdliyyin karena kebanyakan pengajar di TPQ ini memang berlatar belakang Nahdlyyin dengan tetap menjelaskan bahwa ada perbedaan di situ.

Meskipun demikian, kondisi moderatisme juga perlu mendapatkan perhatian khusus. Bahkan, inilah yang boleh jadi menjadi masalah sentral yang ada. Menurut keterangan salah satu pengurus Takmir Masjid al-Fath, di salah satu RT di perumahan Karangploso View terdapat warga menyewa rumah yang merupakan mantan anggota teroris yang baru keluar dari penjara. Meskipun hanya menyewa dan belum bertempat tinggal resmi di perumahan ini, akan tetapi harus tetap mendapatkan atensi yang kuat mengingat radikalisme dan terorisme tengah berkembang marak saat ini. Persoalan radikalisme dan terorisme menjadi persoalan penting karena beberapa perumahan di dekat perumahan Karangploso View nyata-nyata menjadi sarang terorisme. Adanya penangkapan terorisme di Perumahan Griya Permata Alam, Perumahan Permata Regency, dan Perumahan Green Hils pada tahun 2016 menjadi bukti yang tidak bisa dibantah lagi.

Di lingkungan TPQ Nurul Iman sendiri pernah terdapat santri yang bersikap dan berpikir eksklusif, dan begitu pula dengan orang tuanya. Kemudian, setelah beberapa waktu, santri tersebut sudah tidak kelihatan lagi mengaji di TPQ Nurul Iman dan beralih mengaji sendiri di rumahnya. Memang mengaji di TPQ merupakan pilihan, dan begitu pula mengaji di rumah juga adalah pilihan. Hanya saja apabila dibarengi dengan eksklusivitas dalam berpikir dan bertindak tentu saja menjadi masalah yang patut dicarikan solusinya.

TPQ Nurul Iman berada di naungan Masjid al-Fath Perumahan Karangploso View dan belum mempunyai gedung tersendiri. Secara struktural, ia berada dalam seksi Dakwah yang ada dalam struktur ketakmiran masjid. Oleh sebab itu, antara TPQ Nurul Iman dan Masjid alFath mempunyai relasi yang tidak bisa dipisahkan. Kegiatan pembelajaran pun dilaksanakan di Masjid al-Fath, dan oleh karenannya, kegiatan-kegiatan yang nantinya diadakan oleh pengabdi juga berada di lingkungan Masjid al-Fath tersebut. Diharapkan masyarakat sekitar juga tertarik mengikuti kegiatan-kegiatan yang nantinya dilaksanakan.

Dalam pengabdian masyarakat ini, pengabdi mengagas dua bentuk kegiatan dalam jangka wakti tiga bulan (Juli sampai September 2020) sebagai bentuk kontribusi untuk ikut menyelesaikan problematika radikalisme dan terorisme, terlebih lagi sebagai langkah preventif melalui lembaga TPQ Nurul Iman, yakni kegiatan parenting bernuansa wasathiyah dan perpustakaan Qur'ani. Dua kegiatan ini bertujuan membangun moderatisme beragama, atau setidaknya memperkuat moderatisme yang sudah ada, sekaligus menjadi sarana preventif masyarakat TPQ Nurul Iman Perumahan Karangploso View agar terhindar dari doktrin-doktrin radikal. Parenting akan difokuskan pada orang tua santri dan pengajar, dan perpustakaan Qur'ani akan difokuskan pada santri-santri TPQ Nurul Iman. 
Taman Pendidikan al-Qur'an memang seharusnya ikut berkontribusi dalam pemberantasan radikalisme, sebab penanganan terhadap paham-paham radikal harus dimulai sejak pendidikan dasar itu diajarkan. Namun demikian, hal ini sepertinya agak luput dari perhatian para peneliti dan pengabdi yang ada. Beberapa kajian yang ada lebih terfokus pada pemberantasan radikalisme dalam institusi non-TPQ, khususnya pesantren (Amin, Said, \& Efendy, 2018; AS., 2017; Cahyono \& Hamzah, 2018; Fahmi \& Aswirna, 2018; Kusmira, 2018; Ni'am, 2015; Rokhmad, 2012). Meskipun begitu, kajian-kajian tersebut berperan besar dalam memandu jalannya pengabdian ini dan menghantarkan pengabdian ini ke arah gerakan antiradikalisme dengan sistematis.

\section{Metode}

Metode pengumpulan data dan pendampingan yang digunakan dalam pengabdian masyarakat ini adalah PAR (Participatory Action Research) untuk merubah masyarakat TPQ Nurul Iman yang awalnya barangkali berpikiran ekslusif dan radikal dan kemudian mempunyai pemikiran moderat dalam beragama dan berbangsa. Atau paling tidak minimalnya bisa memperkuat moderatisme beragama yang sudah mereka miliki. Dalam PAR ini, pengabdi beserta masyarakat TPQ akan saling bekerja sama untuk menemukan masalah dan mencarikan solusi untuk membangun pemikiran moderat di TPQ Nurul Iman.

PAR sendiri mempunyai beberapa karekteristik (Ridho, 2011). Pertama, PAR merupakan penelitian atau pengabdian yang ditandai dengan keterlibatan aktif masyarakat sebagai kelompok sasaran. Masyarakat ditempatkan sebagai subjek dan bukan objek. Dengan demikian, masyarakat TPQ, yang dalam hal ini meliputi guru-guru, orang tua santri, dan juga sekaligus santri berperan aktif dalam kegiatan. Kedua, dalam PAR, peneliti menempatkan diri sebagai insider dan bukan outsider. Peneliti harus berada di dalam dan bersama-sama masyarakat membangun apa yang menjadi tujuannya. Ketiga, PAR adalah gabungan dari penelitian dan tindakan langsung yang dilakukan secara partisipatif guna meningkatkan kehidupan masyarakat, yang dalam konteks pengabdian ini adalah moderatisme dalam berbangsa dan beragama. Keempat, PAR bertujuan untuk meningkatkan keikutsertaan masyarakat secara aktif dalam kegiatan yang dicanangkan, sehingga tujuan yang diinginkan bisa terwujud.

Metode PAR yang digunakan dalam pengabdian ini dilaksanakan dengan langkah-langkah sebagai berikut (Mufidah Ch, Mahmudi, \& Zuhriah, 2010): Pertama, perencanaan (plan). Perencanaan ini dilakukan setelah memperhatikan kondisi nyata TPQ Nurul Iman dengan menggunakan analisis SWOT. Dalam menganalisis problematika tersebut, dilaksanakan dengan menganalisis kekuatan, kelemahan, peluang dan ancaman yang mungkin terjadi dan hal ini dilakukan dengan melibatkan masyarakat TPQ Nurul Iman. Perencanaan ini meliputi strategi dan metode dalam memecahkan problematika yang dihadapi oleh TPQ Nurul Iman.

Kedua, tindakan (action). Setelah proses perencanaan dilakukan, masyarakat TPQ Nurul Iman mengimplementasikan rencana yang telah dibuat tersebut dengan dibantu dan difasilitasi oleh pengabdi. Ketiga, pengamatan (observe). Pengamatan dilakukan untuk memperhatikan dan menganalisis keberhasilan, kelemahan, dan kekurangan strategi dan metode yang 
digunakan dalam menyelesaikan problematika yang terjadi di masyarakat TPQ Nurul Iman. Demikian pula faktor-faktor pendukung dan penghambat yang teridentifikasi selama kegitan berlangsung.

Keempat, refleksi (reflect). Usaha-usaha yang telah dilakukan dalam memecahkan problematika moderatisme beragama di TPQ Nurul Iman tersebut direfleksikan dan dievaluasi, baik kekurangan, kelemahan, maupun keberhasilan strategi dan metode dalam memecahkan problematika masyarakat tersebut. Refleksi dan evaluasi ini berujung kepada perencanaan ( $p l a n)$ seperti pada poin pertama untuk menuntaskan problematika masyarakat, baik yang belum tuntas pada tahap pertama maupun untuk memecahkan problematika yang baru hingga tercapai masyarakat TPQ Nurul Iman sesuai dengan harapan.

Dua kegiatan dalam pengabdian masyarakat ini dilakukan dengan cara berbeda. Pertama, kegiatan parenting wasathiyah dilakukan dengan mengundang ahli di bidang parenting yang memahami persoalan radikalisme untuk memberikan seminar tentang bagaimana cara mendidik anak dengan cara berpikir moderat-islami. Kegiatan ini dilaksanakan sekali dengan durasi waktu sekitar dua jam di Masjid al-Fath perumahan Karangploso View yang merupakan tempat belajarmengajar TPQ Nurul Iman. Kegiatan ini mengundang wali santri, guru-guru TPQ, para santri, dan juga remaja Masjid al-Fath. Kedua, kegiatan pengadaan perpustakaan Qur'ani dilakukan dengan membeli almari dan buku-buku anak berciri khas Qur'ani-moderat. Dengan demikian, santri-santri TPQ maupun remaja masjid dapat langsung membaca buku-buku tersebut pada jam berapapun. Dalam konteks ini, mereka akan dibimbing oleh pengabdi sendiri dan juga guruguru TPQ Nurul Iman.

\section{Hasil dan Pembahasan}

Dalam pembahasan ini, pengabdi menuliskan terlebih dahulu analisis SWOT terhadap TPQ Nurul Iman yang nantinya menjadi acuan dalam membuat desain pengabdian. Dari data yang diperoleh, selama ini, kegiatan TPQ bisa dikatakan masih minim. Yang biasa berjalan hanya proses belajar mengajar al-Qur'an saja dan beberapa kegiatan tambahan, dan jarang melaksanakan aktifitas-aktifitas tambahan lazimnya di sekolah, seperti parenting. Dengan adanya parenting yang diinisiasi oleh Tim pengabdian kepada masyarakat UIN Maulana Malik Ibrahim Malang ini, diharapkan bisa memantik kegiatan-kegiatan TPQ Nurul Iman yang lain dan bisa berjalan dengan baik.

Dalam aspek sumber daya manusia, TPQ Nurul Iman sebenarnya bisa dikatakan mencukupi. Jumlah guru yang berjumlah tujuh orang menjadi aset penting dalam membangun TPQ ini lebih baik ke depannya. Begitu pula jumlah santri yang cukup banyak, yakni 56 santri, meski disadari bahwa jumlah tersebut masih kalah jauh dengan jumlah anak-anak yang seharusnya mengaji di Perumahan Karangploso View. Walaupun demikian, jumlah tersebut sebenarnya sudah menjadi prestasi tersendiri mengingat TPQ ini sempat terseok-seok dalam dalam beberapa waktu ketika ia pertama kali berdiri.

Peluang yang dimiliki oleh TPQ Nurul Iman cukup besar di Perumahan Karangploso View karena ia merupakan satu-satunya lembaga pendidikan dalam pembelajaran al-Qur'an. Posisi 
penting ini perlu dimaksimalkan, terutama dalam bidang moderatisme beragama yang dilakukan oleh pengabdian kepada masyarakat ini. Pengabdian ini berupaya agar terbentuk masyarakat TPQ Nurul Iman berpandangan moderat terkait keberagamaan dan kebernegaraan mereka. Namun, hal yang harus menjadi perhatian penting adalah warga perumahan ini yang sangat heterogen, sehingga berhati-hati dalam mengambil langkah.

\section{Parenting Wasathiyah}

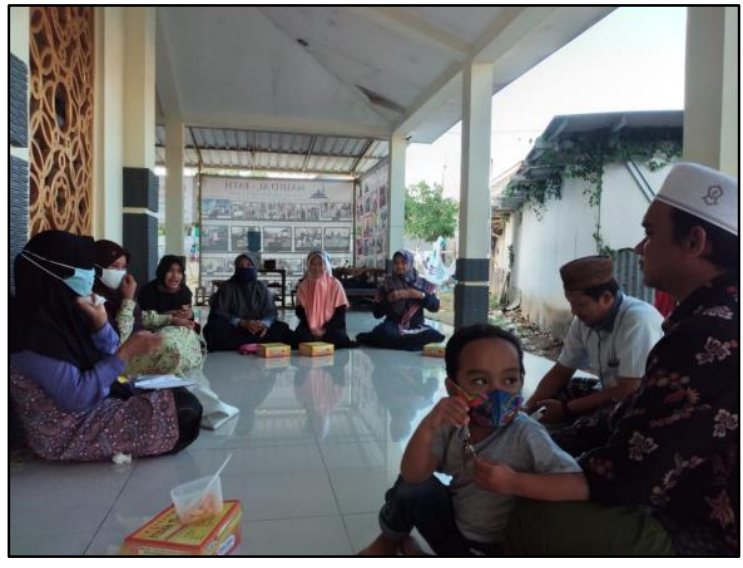

Gambar 1. Rapat dengan guru-guru TPQ

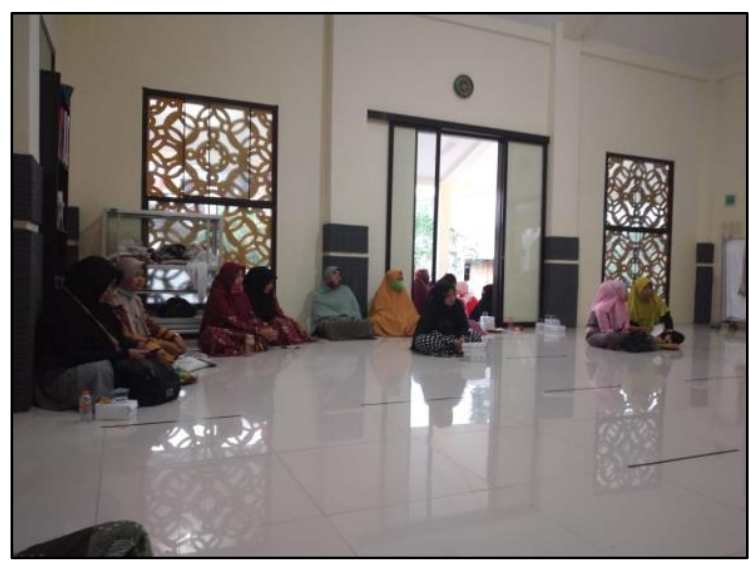

Gambar 3. Peserta kegiatan Parenting

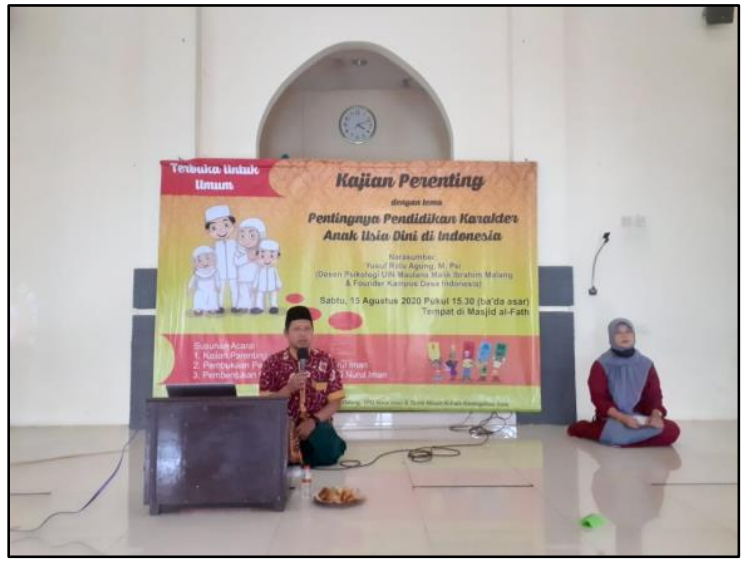

Gambar 2. Sambutan Ketua TPQ

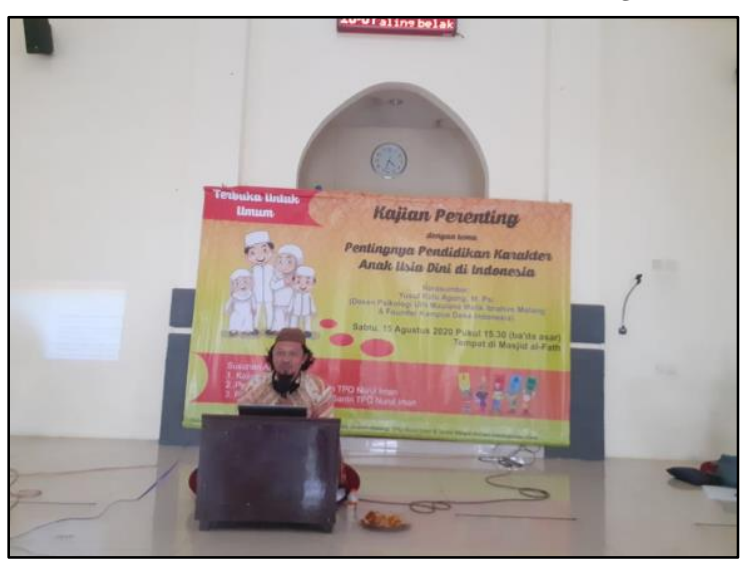

Gambar 4. Pemateri menyampaikan materi

Rapat dengan guru-guru TPQ Nurul Iman pengabdi laksanakan pada tanggal 6 Agustus 2020 setelah selesai mengajar (pukul 16.30 WIB). Sore itu kegiatan belajar mengajar sengaja dipercepat supaya bisa melaksanakan rapat dengan maksimal. Pertama, pengabdi dan guruguru TPQ menentukan kapan kegiatan akan dilaksanakan dan siapa pemateri yang sesuai. Setelah berpikir dan sedikit berdebat, pengabdi dan guru-guru TPQ memutuskan untuk melaksanakan kegiatan pada hari sabtu, tanggal 15 Agustus 2020 dengan pemateri Yusuf Ratu Agung, M. Psi dari Kampus Desa Indonesia sekaligus Dosen Psikologi di UIN Maulana Malik Ibrahim Malang. Dengan demikian, ada sekitar dua minggu untuk persiapan kegiatan parenting.

Tema yang diangkat memang tidak secara eksplisit menggaungkan pemahaman Islam wasathiyah, yakni "Pentingnya Pendidikan Karakter Anak Usia Dini di Indonesia." Hal ini dikarenakan supaya tidak menimbulkan polemik di antara masyarakat TPQ Nurul Iman. Di dalamnya akan dibahas juga mengenai konteks Indonesia yang mempunyai banyak masalah 
seperti terorisme dan juga radikalisme, dan bagaimana harus menyikapinya dalam konteks pendidikan karakter. Dalam parenting ini dilakukan dengan cara yang halus supaya tidak menimbulkan konflik. Ibarat Walisongo yang menyebarkan Islam dengan jalan kultural, itulah yang pengabdi lakukan di TPQ ini.

Hal yang menggembirakan adalah, ternyata beberapa subjek pengabdian yang lain ikut bekerjasama dengan pengabdi untuk menyukseskan kegiatan parenting. Misalnya saja, ada wali santri yang mengajukan diri dan tanpa diminta untuk menyumbangkan konsumsi tambahan dalam acara tersebut. Tidak tanggung-tanggung, direncanakan sekitar dua puluhan piring berisi gorengan yang akan disumbangkan dalam kegiatan parenting. Ini menunjukkan bahwa pengabdi dan masyarakat TPQ Nurul Iman yang merupakan subjek pengabdian, bersama-sama melaksanakan kegiatan parenting sesuai dengan metode PAR yang digunakan.

Banner kegiatan parenting pun dibuat juga, yang meminta tolong kepada sekretaris Masjid al-Fath untuk membuatkannya. Banner pun dibuat dan dicetak, hingga terakhir dipasang di besi besar pengumuman Masjid al-Fath agar dibaca dan diketahui oleh masyarakat perumahan Karangploso View, bukan hanya wali santri TPQ Nurul Iman. Dalam banner tersebut disebutkan bahwa kegiatan ini merupakan kolaborasi antara tim pengabdian UIN Maulana Malik Ibrahim Malang, TPQ Nurul Iman, dan juga Takmir Masjid al-Fath. Juga disebutkan ada tiga acara di dalamnya, yaitu kajian parenting, pembukaan perpustakaan Nurul Iman, dan pembentukan forum wali santri TPQ Nurul Iman. Kegiatan ini terbuka untuk umum dan dituliskan seperti itu di banner tersebut.

Pada hari sabtu tanggal 15 Agustus 2020 dilaksanakan kegiatan parenting wasathiyah. Kegiatan ini diawali dengan sambutan dari ketua TPQ Nurul Iman, M. Mukhlis Fahruddin. Dalam sambutannya, ia berterima kasih atas kegiatan pengabdian yang dilaksanakan oleh Tim Pengabdian UIN Maulana Malik Ibrahim Malang. Ia berharap kegiatan-kegiatan seperti ini bisa berlangsung secara terus-menerus supaya memberikan manfaat bagi masyarakat sekitar. Tidak lupa ia mengajak kepada wali santri supaya kegiatan parenting menjadi tonggak kegiatankegiatan TPQ selanjutnya, karena memang direncanakan, kegiatan parenting akan dilakukan rutin sebulan sekali. Parenting yang dilakukan ini menjadi titik pijak menuju parenting-parenting selanjutnya.

Sambutan yang kedua adalah atas nama Pengabdian UIN Maulana Malik Ibrahim Malang. Dalam sambutan tersebut, pengabdi menyampaikan bahwa kegiatan ini merupakan salah satu bentuk kontribusi UIN Malang untuk membangun masyarakat yang berperadaban. Meskipun banyak kekurangan, seperti parenting yang cukup sederhana dan perpustakaan TPQ yang juga sederhana, diharapkan bisa memberikan manfaat bagi warga perumahan Karangploso View secara umum dan masyarakat TPQ Nurul Iman secara khusus. Pengabdi melanjutkan, bahwa dalam kegiatan parenting, hadirin bisa mengambil ilmu dari pemateri, dan dari pengadaan perpustakaan, anak-anak bisa menambah pengetahuan keislaman yang memadai. Dua kegiatan yang diadakan oleh Pengabdian UIN Malang ini mempunyai tujuan membentuk karakter anak yang islami dan berakhlak mulia.

Pengabdi juga menyampaikan bahwa selain kegiatan parenting ini, pengabdi juga membuat perpustakaan Qur'ani untuk TPQ Nurul Iman yang bisa digunakan santri TPQ untuk 
membaca berbagai macam pengetahuan keislaman. Meskipun bukunya tidak banyak, akan tetapi diharapkan bahwa perpustakaan ini bisa berevolusi menjadi perpustakaan yang besar. Dalam kesempatan ini pula, pengabdi sebagai tim pengabdian UIN Maulana Malik Ibrahim Malang secara resmi menyerahkan perpustakaan Qur'ani kepada TPQ Nurul Iman.

Jika kegiatan parenting ini diamati, maka bisa tampak bahwa antusiasme wali santri memang agak minim terhadap kegiatan ini. Maklum, kegiatan parenting ini menjadi kegiatan pertama kalinya di TPQ Nurul Iman. Ditambah lagi dengan adanya wabah Covid-19 yang tengah melanda dunia termasuk Indonesia, sehingga membuat takut wali santri yang hendak pergi ke Masjid al-Fath guna menghadiri acara parenting ini. Walaupun di Masjid al-Fath dijalankan protol kesehatan, akan tetapi tetap saja sebagian wali santri takut berkumpul dengan orang banyak di satu tempat. Selain itu, memang ada pula yang malas mengikuti kegiatan-kegiatan parenting semacam ini.

Untuk mengatasi masalah yang mendera parenting wasathiyah tersebut, maka Seksi Informasi ketakmiran Masjid al-Fath untuk menyiarkan secara live kegiatan parenting lewat facebook yang dimiliki oleh masjid. Paling tidak dengan hal tersebut, undangan yang berhalangan hadir bisa melihat tayangannya lewat media sosial yang dimiliki oleh Masjid alFath, meskipun disadari bahwa ketidakhadiran wali santri disebabkan oleh beragam alasan yang ada. Diharapkan dengan adanya live kegiatan parenting ini bisa menjadi sarana penyampai pesan pada wali santri yang tidak bisa hadir.

Undangan yang hadir memang kurang dari 20 orang. Namun hal yang cukup menggembirakan adalah datangnya orang tua yang bukan termasuk wali santri TPQ Nurul Iman. Ini berarti, daya tarik yang dimiliki kegiatan ini masih bisa diperhitungkan, meskipun karena wabah Covid-19 menyebabkan yang hadir hanya sedikit. Hadirin terlihat serius mendengarkan materi-materi yang disampaikan oleh pemateri, Yusuf Ratu Agung. Sesekali hadiri tertawa karena mendengarkan candaan yang dilontarkan oleh pemateri.

Pemateri menyampaikan pentingnya pendidikan karakter bagi anak-anak, termasuk santri-santri TPQ. Hal ini dikarenakan banyak sekali masalah-masalah yang mendera kehidupan pada saat ini, mulai dari perkembangan gadget yang tidak terlepaskan dari anak-anak zaman sekarang hingga persoalan bobroknya moral akibat pergaulan yang salah. Menjadi kewajiban bagi orang untuk selalu mendidik anaknya supaya mempunyai karakter yang mulia. Islam pun, lanjut pemateri, mempunyai konsep yang komprehensif terkait dengan cara mendidik anak agar mempunyai karakter atau akhlak yang baik.

Tidak lupa dalam konteks tema yang diusung oleh pengabdi, pemateri juga sedikit menyampaikan bahwa permasalahan tidak berhenti di situ. Indonesia pada zaman sekarang ini sudah sulit terkontrol. Bagaimana tidak, kehidupan sekarang penuh dengan kekerasan yang perilaku radikal. Semua serba disalahkan, terutama yang berbeda. Akibatnya tidak hanya menimpa orang dewasa, bahkan anak-anak pun ikut menjadi korban. Pada beberapa tahun lalu misalnya, terjadi bom bunuh diri di sebuah gereja di Surabaya yang pelakunya satu keluarga dan melibatkan anak-anaknya juga. Inilah salah satu masalah penting yang harus ditangani oleh orang tua pada zaman sekarang untuk mendidikan karakter mulia pada anaknya. 
Kemudian, sebagai kontinuitas kagiatan parenting, TPQ Nurul Iman pun mengadakan parenting-parenting lanjutan yang rencananya dilaksanakan tiap bulan dengan tema yang berbeda-beda. Kegiatan parenting wasathiyah dilakukan ini menjadi batu pijakan untuk kesuksesan parenting-parenting selanjutnya yang dilaksanakan oleh TPQ Nurul Iman. Sekedar informasi, untuk parenting lanjutan telah dilaksanakan pada tanggal 3 Oktober 2020 pada waktu setelah salat maghrib dengan pemateri Muh. Anwar Fuady, S. Psi. MA dengan tema bahaya dan manfaat gadget. Acara dilaksanakan setelah maghrib sendiri adalah dikarenakan supaya hadirin banyak yang hadir. Jadi setelah salat maghrib langsung dilaksanakan kegiatan parenting.

\section{Perpustakaan Qur'ani}

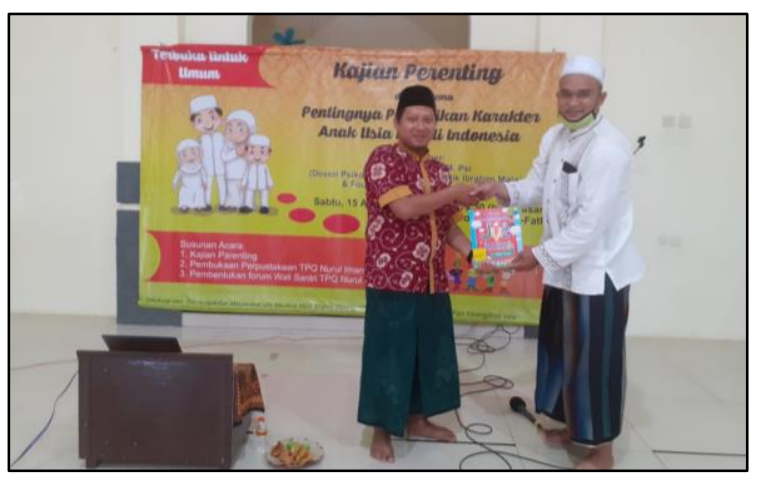

Gambar 5. Serah terima perpustakaan

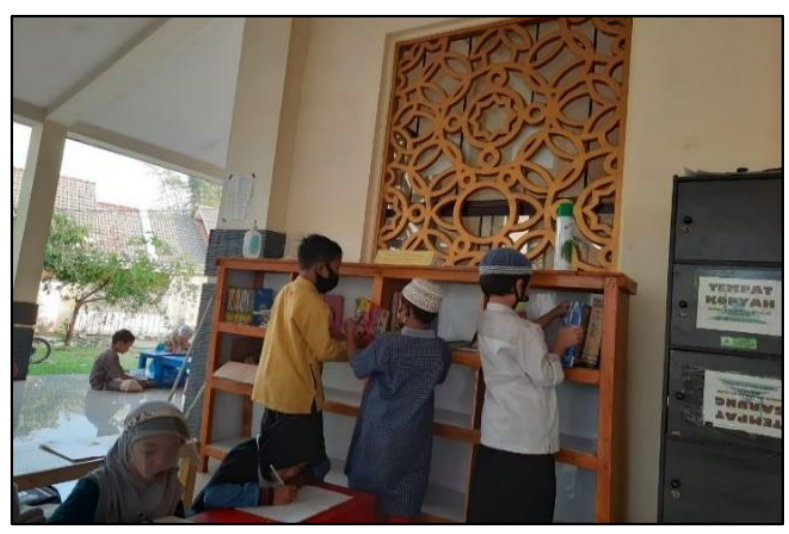

Gambar 7. Santri merapikan buku

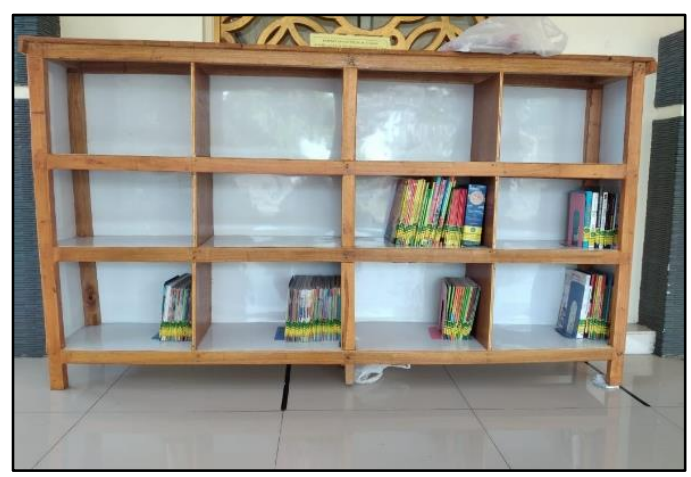

Gambar 6. Bentuk Perpustakaan Qur'ani

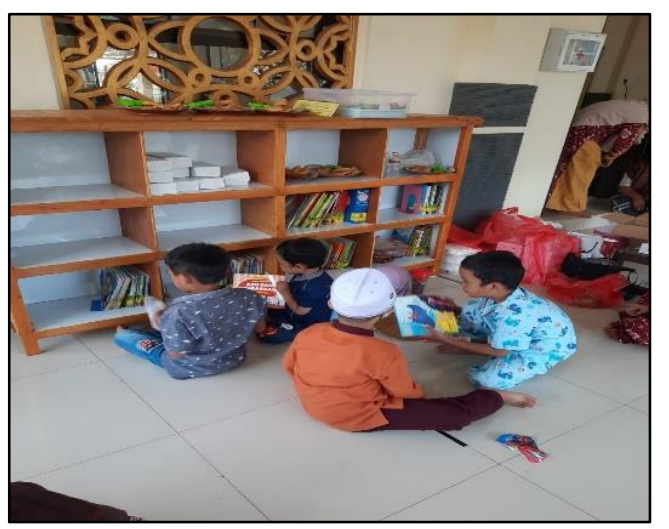

Gambar 8. Santri membaca buku

Pengadaan perpustakaan Qur'ani dilakukan dengan dua tahapan. Pertama, dengan membeli sebuah almari yang dirasa representatif. Karena dana yang diperoleh hanya sedikit dan pertimbangan agar tidak berbahaya apabila dinaiki oleh anak-anak, maka almari yang didapatkan pun berbetuk almari kayu kotak-kotak yang cukup sederhana. Jumlah kotak yang ada adalah dua belas kotak dan mempunyai panjang sekitar setengah meter, sehingga panjang almari adalah sekitar dua meter. Kedua, membeli buku-buku yang dibutuhkan untuk mengonstruksi paham moderat bagi santri-santri TPQ Nurul Iman. Dalam konteks ini, dipilih buku-buku yang mempunyai karakter 3N, yakni No PKI, No Wahabi, dan No HTI. Menurut pengabdi, $3 \mathrm{~N}$ inilah yang mempunyai peran besar dalam membentuk pikiran moderat dalam beragama dan berbangsa. Dengan pola berpikir ini, kemudian, dipetakan menjadi tiga jenis karakter buku, yaitu buku tentang keislaman (terutama al-Qur'an) secara umum yang moderat, 
buku tentang kepesantrenan yang memang menggaungkan moderasi dalam pengajarannya, dan buku tentang keindonesiaan sebagai landasan kecintaan pada negara kita Indonesia. Pengabdi sangat memperhatikan aspek moderatisme, bahkan untuk terjemahan Al-Qur'an saja, pengabdi memilih terjemahan Al-Qur'an Universitas Islam Indonesia (UII) yang menyantumkan $\mathrm{KH}$. Bahauddin Nursalim (Gus Baha) sebagai pentashihnya.

Secara umum, jumlah buku yang terkumpul tidak terlalu banyak karena minimnya dana. Jumlah buku yang bisa terkumpul berkenaan dengan buku-buku keislaman secara umum berjumlah 87 judul, sedangkan buku-buku tentang kepesantrenan berjumlah 10 judul, dan buku-buku tentang keindonesiaan berjumlah 36 judul. Semua judul tersebut mayoritas dari dari pembelian secara langsung, dan sebagian kecil merupakan sumbangan dari wali santri yang mempunyai visi yang sama seperti tema yang ada dalam pengabdian ini. Dalam pengadaan perpustakaan TPQ Nurul Iman ini difokuskan pada buku anak-anak, karena santri TPQ memang masih anak-anak.

Penyerahan perpustakaan ini kepada TPQ Nurul Iman diberikan pada saat kegiatan parenting wasathiyah agar diketahui oleh para wali santri yang hadir pada acara tersebut. Pada hari pelaksanaan parenting tersebut, perpustakaan dan buku-bukunya sudah siap dibaca oleh anak-anak. Selain itu juga, pembinaan kepada anak-anak akan diberikan juga sehingga mereka yang tidak bisa membaca dapat memahami apa yang dimaksud di dalam buku.

Dalam pengadaan perpustakaan ini, para santri tidak dibiarkan membaca buku sendiri, akan tetapi pengabdi terkadang bersama guru-guru TPQ mengarahkan dalam membaca kontenkonten dalam buku. Disadari memang sebagian santri belum bisa membaca dengan baik. Pengabdi bersama guru dengan sabar membacakan dan memberikan makna terhadap kontenkonten yang ada dalam buku tersebut. Pengabdi pun sering bertanya kepada mereka, apakah buku yang ada dalam almari TPQ bagus atau tidak. Mereka menjawab bahwa bukunya bagusbagus, sehingga mereka sering membaca buku-buku tersebut. Misalnya saja Ira, yang merupakan salah satu santri TPQ Nurul Iman berkata "bukunya bagus-bagus, suka baca bukunya, hanya tidak bisa dibawa pulang" (wawancara dengan Ira).

Dalam waktu kegiatan TPQ sendiri, aktivitas membaca buku di perpustakaan biasa dilakukan anak-anak ketika menunggu kehadiran guru. Untuk anak usia pra sekolah kegiatan membaca dilakukan oleh wali santri ketika menunggu giliran mengaji, kegiatan membacakan buku ini dilakukan dengan antusias oleh para wali santri. Di samping itu, para santri selalu diingatkan untuk berlaku disiplin agar merapikan buku-buku yang sudah dibaca. Buku adalah barang yang penting sehingga perlu dijaga, terlebih lagi ini adalah perpustakaan pertama yang dimiliki oleh TPQ Nurul Iman. Mereka pun mengikuti arahan-arahan yang diberikan. Hestu, salah satu wali santri mengungkapkan bahwa dengan adanya perpustakaan TPQ cukup membantu mengalihkan anak-anak ketika menunggu giliran mengaji yang biasanya mereka lari-larian di sekitar masjid. Setiap hari ia berganti-ganti judul buku untuk dibacakan ke anaknya. Dengan itu, mereka jadi bisa duduk dengan tenang dan tertib dan mendengarkan, apalagi menurut Hestu, buku-bukunya menarik untuk anak-anak (wawancara dengan Hestu).

Untuk menangani permasalan masih minimnya buku yang ada di perpustakaan TPQ Nurul Iman, maka pengabdi sudah berkoordinasi dengan ketakmiran Masjid al-Fath dan juga TPQ 
Nurul Iman bahwa buku-buku yang ada di perpustakaan TPQ Nurul Iman harus ditambah dengan memaksimalkan potensi yang ada. Dalam sambutan di acara parenting wasathiyah pun, ketua TPQ sudah memberitahukan kepada wali santri supaya bersama-sama mengisi kotak kosong dalam rak perpustakaan TPQ Nurul Iman sebagai bacaan bagi santri-santri TPQ Nurul Iman pada khususnya dan anak-anak perumahan Karangploso View pada umumnya.

\section{Hasil Kegiatan Parenting Wasathiyah dan Perpustakaan Qur'ani}

Setelah menjalani dua kegiatan yang dilaksanakan dalam pengabdian ini, perlu melihat mengenai hasil yang didapatkan terkait moderasi beragama yang ada di TPQ Nurul Iman. Telaah terhadap hasil ini tidak bisa dilakukan dalam waktu yang bersamaan, sebab keduanya tidak berada dalam satu waktu yang sama. Telaah hasil kegiatan parenting wasathiyah dapat langsung ditelusuri ketika kegiatan tersebut selesai dilaksanakan, sedangkan hasil pengadaan perpustakaan Qur'ani baru bisa diamati tatkala beberapa minggu bahkan beberapa bulan setelah perpustakaan selesai diserah-terimakan. Perlu waktu agar anak-anak banyak membaca buku yang disediakan perpustakaan.

Sebelum melangkah pada hasil yang didapatkan dalam dua kegiatan ini, perlu kiranya untuk membahas mengenai moderasi beragama itu sendiri yang menjadi tujuan pengabdian ini. Secara mudahnya, moderat artinya berada di tengah-tengah, dan tidak condong ke salah satu kubu ekstrem (Abdurrohman, 2018; Hilmy, 2012; Suharto, 2014). Moderat dalam bahasa Arab diredaksikan dengan wasathiyah. Kata ini dan derivasinya disebutkan beberapa kali dalam al-Qur'an, misalnya QS. al-Baqarah [2]: 142 dengan kata isim (kara benda), QS. al-Qalam [68]: 28 dengan kata fi'il (kata kerja), dan QS. al-Maidah [5]: 89 dengan kata sifat. Adanya kata wasath beserta derivasinya yang banyak disebutkan al-Qur'an menunjukkan bahwa umat Islam harus menjadi penengah, tidak subjektif, tidak terlalu condong ke sebelah pihak, menjadi orang yang paling fasih dalam kebaikan serta selalu menyebarkan kedamaian di atas muka bumi (Ardiansyah, 2016).

Pada hakikatnya, Islam mempunyai karakteristik wasathiyah, atau moderat, sebab ia menjadi jalan tengah antara Yahudi yang terlalu ekstrem dan Nasrani yang terlalu lunak. Nabi Muhammad sendiri sebagai uswah umat Islam, sangat menghargai sisi kemanusiaan seseorang, baik muslim atau non-muslim (Afwadzi \& Alifah, 2019). Selain beragama, dalam hal bernegara pun harus mempunyai sikap moderat (Umam, 2019). Dalam ajarannya, syariat Nabi mempunyai prinsip dan karakter yang berintikan moderasi. Beberapa prinisp dan karakter tersebut adalah, pertama, al-khairiyyah (terpilih atau terbaik), dan wasathiyyah sendiri mempunyai makna, salah satunya, adalah terpilih atau terbaik; kedua, al-'adalah (bersikap adil) yang merupakan perintah Allah dalam berbagai firman-Nya; ketiga, al-tawazun (kesimbangan), yang berarti memberikan sesuatu akan haknya tanpa adanya penambahan atau pengurangan; keempat, tasamuh (toleran), yang mempunyai arti tenggang rasa atau sikap menghargai dan menghormati sesama manusia, baik muslim maupun non-muslim; kelima, al-istiqamah (konsisten) dalam membela kebenaran dan menghindarkan dari penyimpangan; keenam, raf'u al-haraj (menghilangkan kesulitan) karena Islam merupakan agama yang mudah dan tidak mempersulit umatnya (Ardiansyah, 2016). 
Meskipun demikian, pada wilayah faktualnya, pemahaman tentang moderat dan siapa yang berhak disebut sebagai Muslim moderat memang sulit untuk diidentifikasi secara konklusif. Ini disebabkan interpretasi terhadap kata moderat sendiri dipahami secara subjektif oleh banyak kalangan. Masing-masing menafsirkan kata moderat tersebut sesuai dengan kepentingannya sendiri-sendiri. Dalam tradisi Islam klasik pun, sebenarnya tidak ditemukan istilah moderat sebagai sebuah terminologi khusus, meskipun saat ini ia dikonotasikan dengan beberapa istilah, khususnya al-tawassuth. Istilah moderatisme pada masa sekarang, oleh banyak kalangan lebih dimaknai sebagai model keagamaan yang damai dan tanpa kekerasan (Hilmy, 2013). Secara lebih jelas, moderatisme biasanya dipahami sebagai pemikiran dan praktik keagamaan yang berada di tengah-tengah dan tidak mengadopsi salah satu kutub ekstrem, baik liberal khas Barat (kiri) maupun Islam radikal (kanan) (Hilmy, 2013).

Menurut Masdar Hilmy, Islam moderat mempunyai beberapa ciri: pertama, menyebarkan Islam dengan tanpa dibarengi dengan kekerasan; kedua, mengadopsi cara hidup modern beserta turunannya, seperti ilmu pengetahuan dan teknologi, demokrasi, dan hak asasi manusia; ketiga, mengedepankan cara berpikir rasional; keempat, memahami Islam dengan pendekatan kontekstual; dan kelima, melakukan ijtihad terhadap sebuah kasus yang tidak dipaparkan secara eksplisit dalam al-Qur'an dan hadis. Kelima ciri tersebut, bagi Masdar Hilmy, bisa diperluas menjadi beberapa ciri lagi, misalnya toleransi, kerukunan, dan kerjasama antar kelompok agama yang berlainan (Hilmy, 2013).

Lawan dari moderatisme biasa diidentikkan dengan radikalisme yaitu beragama dengan mengedepankan kekerasan. Secara umum, radikalisme dapat dipetakan menjadi dua tingkatan. Pertama, radikal dalam tataran pemikiran, yang dimanifestasikan dengan wacana, konsep, dan gagasan yang masih diperbincangkan untuk mendukung cara-cara kekerasan guna mencapai tujuan tertentu. Kedua, radikal dalam tataran aksi, yakni radikal yang benar-benar dilakukan dan tidak hanya dalam bentuk pikiran semata. Radikalisme sendiri bisa berada pada wilayah sosial-politik dan juga agama (AS., 2017).

Rubaidi menyebutkan ada beberapa ciri gerakan radikalisme, meskipun ada ciri yang sebenarnya bisa diperdebatkan. Pertama, menjadikan Islam sebagai ideologi final dalam mengatur kehidupan individual dan juga politik ketatanegaraan. Kedua, nilai-nilai Islam yang dianut mengadopsi sumbernya di Timur Tengah secara apa adanya tanpa mempertimbangkan perkembangan sosial dan politik ketika al-Qur'an dan hadis hadir di muka bumi ini, dengan realitas lokal kekinian. Ketiga, karena perhatian lebih terfokus pada teks al-Qur'an dan hadis, maka purifikasi ini sangat berhati-hati untuk menerima segala budaya non asal Islam (budaya Timur Tengah) termasuk berhati-hati menerima tradisi lokal karena khawatir mencampuri Islam dengan bidah. Keempat, menolak ideologi Non-Timur Tengah termasuk ideologi Barat, seperti demokrasi, sekularisme dan liberalisme. Sekali lagi, segala peraturan yang ditetapkan harus merujuk pada al-Qur'an dan hadis. Kelima, gerakan kelompok ini sering berseberangan dengan masyarakat luas termasuk pemerintah. Oleh karena itu, terkadang terjadi gesekan ideologis bahkan fisik dengan kelompok lain, termasuk pemerintah (Rubaidi, 2010).

Berbekal teori-teori di atas, pengabdi mengambil kriteria standar sebagai tolak ukur keberhasilan kegiatan pengabdian dalam membangun moderasi beragama, yaitu adanya 
kesadaran dalam beragama harus berada di tengah-tengah, tidak berada di ekstrem kanan maupun kiri. Kesadaran untuk mencintai Indonesia dan menjauhi segala tindakan radikal dan teror juga menjadi kriteria yang dipakai oleh pengabdi. Lebih lanjut, setelah menjalani dua kegiatan berupa parenting wasathiyah dan pengadaan perpustakaan Qur'ani serta pembinaannya bisa dikatakan terjadi kemajuan dalam aspek pemahaman moderat bagi masyarakat TPQ Nurul Iman berupa guru, santri, dan wali santri. Atau paling tidak, kegiatankegiatan yang dijalankan mampu lebih mengukuhkan moderatisme yang sudah terpatri dalam diri masyarakat TPQ. Setelah menjalani diskusi dalam beberapa waktu di Masjid al-Fath, pemahaman pada keislaman yang ramah dalam beragama dan bernegara cukup dapat terwujud. Masyarakat binaan sedikit banyak menyadari bahwa tidak boleh berpikir terlalu condong ke kiri dan ke kanan. Pemikiran Islam harus berada di tengah-tengah, yang dalam konteks ini sesuai dengan yang diajukan, yaitu moderat. Meskipun demikian, disadari bahwa proses untuk benar-benar menjadi moderat membutuhkan waktu yang tidak sebentar seperti pengabdian ini. Diperlukan pendampingan-pendampingan lanjutan sebagai kontinuitas kegiatan ini.

Beberapa wali santri yang diwawancarai oleh pengabdi ketika selesai parenting wasathiyah mengungkapkan bahwa mencintai Indonesia merupakan hal yang sangat penting. Ketika kita beragama yang dalam hal ini adalah Islam tidak melupakan jati diri sebagai orang Indonesia. Selain itu, mereka juga menyatakan bahwa aktivitas terorisme dan radikalisme harus dijauhi karena bertentangan dengan prinsip sebagai orang Islam. Secara lebih konkret, dalam wawancara singkat dengan wali santri TPQ Nurul Iman, mereka sebagai salah satu subjek dampingan mampu: pertama, bangga terhadap Indonesia; kedua, memahami bahwa radikalisme dan terorisme adalah perbuatan keji; ketiga, dalam berislam harus bersikap ramah pada yang lain. Begitu pula ketika pengabdi bertanya santai pada anak-anak yang suka membaca di perpustakaan TPQ Nurul Iman. Ketika pengabdi bertanya, apakah kalian cinta Indonesia? Mereka menjawab bahwa mereka sangat menyukai Indonesia sebagai tanah airnya. Begitu pula tatkala apakah kalian suka kekerasan? Mereka menjawab bahwa mereka tidak suka kekerasan karena Islam melarang kekerasan dan hidup harus berada dalam kondisi damai.

Dari seluruh penjelasan di atas dapat dipahami bahwa dua kegiatan yang digagas oleh pengabdi, baik parenting wasathiyah maupun perpustakaan yang bernuansa Qur'ani dirasa mampu menjadi jembatan untuk membangun moderatisme beragama masyarakat TPQ-dengan berbagai kelemahannya-, atau setidaknya bisa menguatkan pemahaman keagamaan moderat yang dimiliki oleh mereka; yang sudah moderat bisa lebih menguatkan moderatnya. Tentunya hal ini sangat penting mengingat arus radikalisme dan terorisme kian kencang menerpa pada masa kontemporer ini. Terlebih lagi, membangun moderatisme dengan fokus pembinaan anak sejak usia dini lewat Taman Pendidikan al-Qur'an kerapkali dilupakan dan lebih terfokus pada wacana-wacana yang seringkali sulit diterima masyarakat awam.

\section{Kesimpulan}

Kegiatan yang dijalankan dalam pengabdian masyarakat ini ada dua bentuk kegiatan, yakni parenting wasathiyah dan pengadaan perpustakaan Qur'ani. Kegiatan parenting 
dilaksanakan pada hari Sabtu tanggal 15 Agustus 2020 dengan mengundang Yusuf Ratu Agung, M. Psi. dari Kampus Desa Indonesia. Kegiatan ini mempunyai kendala undangan yang hadir tidak terlalu banyak karena masih dalam kondisi pandemi. Solusi yang dilakukan adalah dengan menyiarkan secara live lewat akun facebook Masjid al-Fath. Sementara itu, kegiatan pengadaan perpustakaan Qur'ani dilakukan dengan membuat perpustakaan anak-anak yang berisi bukubuku yang berhaluan moderat yang disebut pengabdi dengan 3 N (No PKI, No Wahabi, dan No HTI). Pengabdi dan guru-guru TPQ mendampingi santri-santri yang membaca di perpustakaan ini. Kendala yang ada di perpustakaan ini berupa masih minimnya buku yang ada. Solusi yang dilakukan adalah berkoordinasi dengan Takmir Masjid dan masyarakat untuk bersama-sama menambah buku-buku perpustakaan TPQ.

Hasil dan perubahan yang didapatkan pada subjek binaan cukup baik, yakni adanya kesadaran moderasi dalam berbangsa dan bernegara. Moderatisme beragama dalam masyarakat binaan dapat terbangun dengan baik, atau paling tidak, moderatisme yang sudah mereka yakini sejak awal semakin semakin kuat. Mereka menyadari bahwa harus adanya kecintaan terhadap Indonesia dan adanya kesadaran bahwa perbuatan radikalisme dan terorisme merupakan perbuatan yang keji. Walaupun demikian, pengabdi menyadari bahwa waktu yang singkat belumlah benar-benar dapat merubah pemahaman-pemahaman yang cenderung radikal dan teror dan itu butuh waktu yang panjang, akan tetapi sedikit banyak paling tidak pengabdian kepada masyarakat ini ikut berkontribusi ke arah itu.

\section{Ucapan Terima Kasih}

Pengabdi mengucapkan terima kasih kepada TPQ Nurul Iman dan juga Ketakmiran Masjid al-Fath yang bersedia menjadi subjek binaan dalam pengabdian kepada masyarakat ini, sekaligus direpotkan dalam pelaksanaan kegiatan parenting wasathiyah dan perpustakaan Qur'ani. Tidak lupa pula kepada Lembaga Pengabdian dan Pengabdian Kepada Masyarakat Universitas Islam Negeri Maulana Malik Ibrahim Malang yang membiayai pengabdian kepada masyarakat ini.

\section{Referensi}

Abdurrohman, A. (2018). Eksistensi Islam Moderat dalam Perspektif Islam. Rausyan Fikr, 14(1), 29-41. Adhiarso, D. S. (2019). The Influence of Watching News About Church Bombings in Surabaya on the Public Perception Toward the Veiled Muslim Women in Yogyakarta. Ulul Albab: Jurnal Studi Islam, 20(2), 284-301. https://doi.org/10.18860/ua.v20i2.5662

Afwadzi, B., \& Alifah, N. (2019). Malpraktek dan Hadis Nabi: Menggali Pesan Kemanusian Nabi Muhammad saw. dalam Bidang Medis. Al Quds: Jurnal Studi Alquran Dan Hadis, 3(1), 1-20. https://doi.org/10.29240/alquds.v3i1.772

Amin, S. J., Said, Z., \& Efendy, R. (2018). Encountering Religious Radicalism in The Islamic Boarding School of Nurul Azhar Talawe in Sidrap District South Sulawesi. In R. N. Indah (Ed.), International Conference On University-Community Enggagement. Malang: Ministry of Religious Affairs.

Aminuddin, M. (2016). Ini Kronologi Penangkapan Teroris di Malang. Retrieved from https://news.detik.com/berita/d-3147011/ini-kronologi-penangkapan-teroris-di-malang

Ardiansyah, A. (2016). Islam Wasațiyah dalam Perspektif Hadis: Dari Konsep Menuju Aplikasi. Mutawatir: Jurnal Keilmuan Tafsir Hadis, 6(2), 232-256. 
https://doi.org/10.15642/mutawatir.2016.6.2.232-256

AS., A. S. (2017). Radikalisme Agama (Analisis Kritis dan Upaya Pencegahannya Melalui Basis Keluarga Sakinah). Sumbula, 2(1), 352-376.

Cahyono, H., \& Hamzah, A. R. (2018). Upaya Lembaga Pendidikan Islam dalam Menangkal Radikalisme. At-Tajdid, 2(1), 17-36. https://doi.org/10.24127/att.v2i01.857

Fahmi, R., \& Aswirna, P. (2018). Moderation of Islam in Islamic Boarding School: Study at Gontor Daussalam Modern Islamic Boarding School. In R. N. Indah (Ed.), International Conference On University-Community Enggagement. Malang: Minstry of Religious Affairs.

Hambali, Y. (2010). Hukum Bom Bunuh Diri Menurut Islam Radikal dan Islam Moderat. Maslahah, 1(1), 40-64. https://doi.org/10.33558/maslahah.v1i1.1200

Hilmy, M. (2012). Quo-Vadis Islam Moderat Indonesia? Menimbang Kembali Modernisme Nahdlatul Ulama dan Muhammadiyah. Miqot, 36(2), 262-281.

Hilmy, M. (2013). Whither Indonesia's Islamic Moderatism?: A Reexamination on the Moderate Vision of Muhammadiyah and NU. Journal of Indonesian Islam, オ1), 24-48. https://doi.org/10.15642/JIIS.2013.7.1.24-48

Kusmira, D. (2018). Moderatism of Pesantren Education in Indonesia. Jurnal Ilmiah Pesantren, 4(2), 527-542. Retrieved from http://jurnal.assalaam.or.id/index.php/dfg/article/view/37

Lutfiyah, L., Tamam, A. B., \& Muniroh, A. (2016). Deradikalisasi Pemahaman Alquran: Pendampingan Masyarakat Rawan Terpengaruh Gerakan Islam Garis Keras. Mutawatir: Jurnal Keilmuan Tafsir Hadis, 6(1), 85-112. https://doi.org/10.15642/mutawatir.2016.6.1.85-112

Mufidah Ch, Mahmudi, Z., \& Zuhriah, E. (2010). Pemberdayaan Mutu Remaja Miskin Perkotaan di Kelurahan Kasin, Kec. Klojen, Kota Malang. Malang. Retrieved from http://repository.uinmalang.ac.id/627/1/riset-pemberdayaan.pdf

Ni'am, S. (2015). Pesantren: The Miniature of Moderate Islam in Indonesia. Indonesian Journal of Islam and Muslim Societies, 5(1), 111-134. https://doi.org/10.18326/ijims.v5i1.111-134

Ridho, M. Z. (2011). Signifikansi Metode PAR dalam Pemberdayaan Ekonomi Umat (BAZDA Kabupaten Serang). DEDIKASI, 1(3), 1-13.

Rokhmad, A. (2012). Radikalisme Islam dan Upaya Deradikalisasi Paham Radikal. Walisongo: Jurnal Penelitian Sosial Keagamaan, 20(1), 79-114. https://doi.org/10.21580/ws.20.1.185

Rubaidi, R. (2010). Radikalisme Islam, Nahdlatul Ulama: Masa Depan Moderatisme Islam di Indonesia. Yogyakarta: Logung Pustaka.

Suharto, T. (2014). Gagasan Pendidikan Muhammadiyah dan NU Sebagai Potret Pendidikan Islam Moderat di Indonesia. Islamica: Jurnal Studi Keislaman, 9(1), 81-109. https://doi.org/10.15642/islamica.2014.9.1.81-109

Sumbulah, U. (2009). Konfigurasi Fundamentalisme Islam. Malang: UIN Malang Press.

Sumbulah, U. (2018). Mencegah Radikalisme Melalui Penanaman Nilai-Nilai Multikultural Sejak Usia Dini. In M. Karim (Ed.), Memutus Mata Rantai Ekstremisme Agama. Malang: UIN-Maliki Press.

Suprapto, R. (2014). Deradikalisasi Agama Melalui Pendidikan Multikultural-Inklusiv (Studi pada Pesantren Imam Syuhodo Sukoharjo). PROFETIKA: Jurnal Studi Islam, 15(2), 246-260. https://doi.org/10.23917/profetika.v15i02.2001

Umam, F. (2019). Ideological Involution of the Islamists. Ulul Albab: Jurnal Studi Islam, 20(1), 25. https://doi.org/10.18860/ua.v20i1.5714

Wicaksono, H. (2018). Analisis Kriminologis: Serangan Bom Bunuh Diri di Surabaya. Deviance: Jurnal Kriminologi, 2(2), 88-101. 